\title{
Byer og metropoler - avantgarde og kraftcentre
}

\author{
Interview med Bruce J. Katz
}

I bogen The Metropolitan Revolution beskriver Bruce J. Katz byernes udvikling i USA som en hurtigt voksende bevægelse og kraft, der vil ændre USA's samfundsmæssige landskab så vidtgående, at man kan tale om 'metropolernes revolution'. Udenrigs har med udgangspunkt i bogen interviewet Bruce J. Katz.

Du taler om, at der er en revolution $p a ̊$ vej i USA. En 'metropolernes revolution'. Hvad bygger du det på?

USA's 100 største metropoler udgør 12 pct. af USA's territorium, to tredjedel af USA's samlede befolkning og står for 75 pct. af landets BNP. Byer og metropoler er i stigende grad begyndt at organisere sig og arbejde strategisk.

På verdensplan ser man flere og flere eksempler på byer som acceleratorer og kraftcentre i udvikling af handel og tiltrækning af udenlandske investeringer. Det gør de blandt andet ved at udvikle den infrastruktur, der er nødvendig for at understøtte en dynamisk økonomisk udvikling, og ved at indgå i et tæt samarbejde med virksomheder, universiteter og andre lærings- og forskningsmiljøer. Det giver dem synlighed og indflydelse også på andre områder.

Men det er ikke kun som økonomiske vækstcentre, at byer har et stort potentiale og kan drive den nationale udvikling. I stigende grad løser de problemer, som traditionelt er forsøgt løst på føderalt niveau eller på landspolitisk plan.

Eksemplerne er efterhånden mange verden over, hvor vi ser, at byer går ind og tager ansvar og finder løsninger i forhold til uddannelse, integration, flygtningespørgsmål, klimaforandringer og målet om bæredygtig udvikling og udryddelse af fattigdom. Det gør de ved at tage sagen i egen hånd frem for at vente på, at politikerne på landspolitisk niveau er klar med politiske initiativer.

Hvad har skabt denne forandring $i$ byernes rolle?

Både i USA og i nogen grad i EU har de føderale og nationale politikeres forsøg på at finde løsninger ikke slået til. De har tilmed virket magtesløse på en lang række områder. Det er meget tydeligt i USA, hvor folk har været vidne til frugtesløse konflikter og fjendskab mellem den føderale regering og individuelle stater om midler og indflydelse samt konflikter mellem kongressen og præsidenten. Det har medvirket til at skabe politikerlede.

Det er også symptomatisk for EU. Fx i Spanien, hvor hverken EU, regering eller

Bruce J. Katz var i 20 år vicepræsident og direktør for Brookings Metropolitan Program, som han etablerede i 1996. 
de enkelte regioner kan løse problemerne med den store arbejdsløshed og behovet for økonomisk vækst. I modsætning til dette fremstår byerne som tværfaglige, samarbejdende og løsningsorienterede.

Stater er organiseret i brancheministerier, dvs. i isolerede sektorer, som har svært ved at arbejde integreret på tværs af forskellige brancher og kompetencer. Byer har en tættere interaktion og kontakt med deres borgere og kan reagere hurtigt i forhold til at udvikle løsninger, der involverer aktører fra forskellige brancher, til at udvikle de bedste og mest effektive løsninger på borgernes problemer. De fungerer dermed som en slags 'one stop shop' for borgerne.

Byernes evne til at finde løsninger og tilpasse sig en dynamisk verden beror på at byer har en anden struktur og organisation end stater. De er i deres struktur meget mere fleksible, de er en slags levende organisme. Byer er baseret på netværk, som arbejder med netværk og i netværk. Derfor er det naturligt for dem at gå sammen i netværk, udvikle planer for samarbejde og udveksle erfaringer.

Byer adskiller sig fra lande ved at de er bedre i stand til at observere, kopiere og tilpasse de bedste løsninger, 'best practices', fra andre byer. Der foregår et stort omfang af informationsudveksling på alle niveauer, og der er en mindre tilbøjelighed til at være protektionistisk eller for stolt til at lære af, hvad andre gør.

I en by opleves problemerne som akutte: hjemløshed, ungdomsarbejdsløshed og forurening er straks synligt. Du kan ikke bare løse problemer ved at sige 'lad os lave en lov' eller 'lad os nedsætte en kommission'. Den direkte linje til borgerne resulterer i et øjeblikkeligt krav om hurtige løsninger. Tidshorisonten og tidsfornemmelsen er dermed en helt an- den hos en borgmester end hos en guvernør eller en politiker i kongressen. Problemer opleves som akutte og kræver hurtig handling.

Tag fx Berlin, som i 2015 modtog et enormt antal flygtninge, som bystyret skulle finde boliger til. Derved opstod en akut krise og et øjeblikkeligt behov for en løsning. Flygtningene blev installeret i containere på kort og mellemlang sigt. Disse containere var slet ikke dårlige, og nu har andre byer kopieret modellen fra Berlin - og ikke kun byer i Tyskland. Berlin havde ikke tid til at vente på, at delstats- eller forbundsregeringen fandt på en løsning

Ligeledes kan en borgmester og politiker i en by bedre tillade sig at være pragmatisk i stedet for ideologisk. Man vil oftere opleve utænkelige partimæssige konstellationer om opgaver i et byråd end i det nationale parlament. I et partisystem på landspolitisk plan er det helt andre mekanismer, der gør sig gældende. Det kræver andre taktikker.

I partisystemet på landsplan belønnes du sjældent for at skabe løsninger for borgerne, men man belønnes for at vinde politiske og ideologiske kampe.

Er der en sarlig trylleformular, der kendetegner de storbyer, som udgør fortroppen $i$ byernes revolution? Hvad er det, som karakteriserer dem?

De fleste af de metropoler eller storbyer, der i dag har succes nationalt såvel som på verdensplan, har en række kendetegn til fælles; alle har de en klar profil; brand og viden om byens komparative fordele; et tydeligt lederskab fra byens folkevalgte; et velfungerende samarbejde med vidensinstitutioner; tilstrækkelig menneskelig kapital og fortsat evne til at tiltrække gode menneskelige ressourcer; 
en samarbejdende kultur; eksistensen af velfungerende netværk på tværs af sektorer; offentligt-privat samarbejde og samarbejder med velgørende fonde og civilsamfund.

Det er også vigtigt, at der er en hvis portion af risikovillighed, og at det økonomiske fundament baserer sig på fremtidens teknologier.

Det er ligeledes bydende nødvendigt, at den politiske ledelse i byerne har fokus på almindelige levevilkår. Hvis byer skal skabe innovative områder og universiteter, hvor start-ups og investorer arbejder tæt sammen, skal byerne samtidig være i stand til at tilbyde boliger, som kan betales, praktik og lærepladser, et ordentligt skolesystem og et godt bymiljø.

\section{Er der forskel på byernes udvikling i USA og Europa?}

Både USA og EU indeholder hver i sær så megen forskellighed, at det er svært at lave en meningsfuld sammenligning. Dog kan jeg konstatere, at der i det nordlige Europa eksperimenteres med forskellige former for innovativ finansiering af nye initiativer. Der er en stor interesse i offentligt-private partnerskaber, hvor offentlig finansiering kombineres med samarbejde med private firmaer, som frembringer nye produkter og løsninger, som så kan sælges over hele verden.

Et godt eksempel fra Danmark og København er etableringen af Udviklingsselskabet By \& Havn I/S, som er et samarbejde mellem staten og Københavns Kommune, og hvis formål primært er at udvikle arealerne i Ørestad og Københavns Havn samt forestå havnedrift i Københavns Havn. Det er et rigtig smart design, der formentlig vil blive kopieret $\mathrm{i}$ både USA og Latinamerika.

USA har derimod en overflod af kao- tisk privat innovation, og virksomhederne arbejder i klynger, som arbejder sammen med forskningscentre og 'start-up'-virksomheder. I USA er tidshorisonten for et forskningsprodukts vej fra udvikling til præsentation på markedet meget kort, og generelt er investorer meget risikovillige. Derved skaber vi i USA meget teknologisk innovation, og det er det momentum, som de dygtige ledere af byer er i stand til at gribe. Pittsburg er fx den første by, som brander sig inden for robotindustrien og reklamerer samtidig med at være den første by med førerløse køretøjer.

Du taler i din bog om en serlig form for lederskab, som kendetegner byer med succes?

Det er i dag tydeligt, at de varige forandringer og forbedringer i USA's økonomi efter finanskrisen ikke primært stammer fra initiativer fra det føderale politiske niveau, som det var tilfældet under den Store Depression i 1930'erne, men at de er skabt af et netværk af lederskab i byerne og metropolerne.

Det er et lederskab, som består af politisk valgte ledere fra byer og metropoler, dvs. borgmestre, men også ledere af virksomheder, universiteter, brancheorganisationer, fagforeninger, miljøorganisationer, kulturelle institutioner og private fonde. Disse ledere tager udgangspunkt i det, som giver reel økonomisk værdi: produktion, innovation, teknologi, avancerede tjenesteydelser og eksport.

Den amerikanske kultur belønner dem, som handler først og bevæger sig ud i ukendt farvand. Fx når Pittsburg er den første by til at introducere førerløse biler, eller når Portland udvikler en egentlig handelsstrategi baseret på udvikling af Portland som en grøn by og dermed skaber byens særlige brand, som så tiltrækker interesse og kapital. Men samarbejde 
og utålmodighed efter resultater er kernen i lederskabet. Det vil sige, at det politiske lederskab oplever, at det er bydende nødvendigt at agere, og derved bliver risikovilligt og entreprenant.

\section{Med byernes voksende rolle og indflydel-} se er der så ikke en risiko for, at staternes autoritet bliver undermineret?

Hvis stater skal forblive relevante for borgerne i 'byernes revolution' så er det vigtigt at staten forstår sin egentlige rolle og opgave i relation til byerne.

Bystyret er tættere på borgerne og kan derfor bedre forstå borgernes behov, og hvordan man designer de bedste løsninger. Metropolernes revolution i USA kan kun føre til én logisk konklusion: at magthierarkiet bliver vendt på hovedet. Den øverste udøvende og lovgivende magt skal fortsat have sikkerheds-, forsvars- og udenrigspolitik som sit domæne, udligne eller afbøde konsekvenserne af ulighed og sikre minimumsstandarder for de dårligst stillede og marginaliserede dele af befolkningen samt skabe sikkerhed for disse grupper. Det er de områder, hvor staten på det landspolitiske niveau har en vigtig rolle at spille. Men desværre overskrider nationale regeringer og lovgivere ofte grænserne og blander sig i lokale prioriteter.

Lande, som forstår byernes kraft, kan frigøre et helt enormt potentiale i alle dele af samfundet. Det er den nye vej frem.

Jeg ser, at Danmark, ved dets størrelse og ved at være smart, høster fordelene ved urbaniseringen ved at skabe et samspil mellem de to niveauer: nationalstaten og byerne. Det sker i og med at det danske Erhvervs- og Vækstministerium har en omfattende, overordnet og inkluderende tilgang til eksportfremme og stiller sig til rådighed som en platform, samt skaber rammerne for innovation og samarbejde. Både Udenrigsministeriet og Erhvervs- og Vækstministeriet har påtaget sig en klar opgave i at hjælpe med at udvide og ekspandere dansk erhvervsliv og danske varer uden for landets grænser.

Dermed har ministeriet defineret sin rolle i forhold til virksomheder og byer. Det er meget interessant også for os i USA. I tillæg til dette så har Danmark tidligere end andre lande politisk besluttet at påtage sig en opgave med at være et land med lave $\mathrm{CO}_{2}$-udledninger. Derved bliver Danmark en 'first mover' og er med til at sætte dagsordenen.

Med udgangspunkt i den politiske beslutning skabes der incitamenter for virksomhederne til at udvikle teknologier, som kan sikre vækst på baggrund af kulstoffattig produktion.

\section{Hvilken rolle spiller byer i udenrigspolitik?}

Byer eksisterer inden for staten, men transcenderer også nogle gange disse. Fx når byer agerer kollektivt på den globale scene som i C40-netværket omkring klimamålene.

Byer er ikke regerende, de udgør netværk - dvs. et 'Centre of Excellence' opretter forbindelse til et andet 'Center of Excellence' $i$ en anden by eller andet land derved bevæger information og vidensdeling sig hurtigere på tværs af grænser, og dermed skabes der mulighed for innovation og udvikling.

I en globaliseret verden vil evnen til at absorbere og transformere information gennem det at kunne skabe forbindelser og netværk definere, om du vinder eller taber. Byer er per definition organiseret og repræsenteret af en lang række aktører og er i deres arbejdsform samarbejdende 
- en levende organisme - og derved åbne over for ny viden og et ønske om at identificere gode løsninger.

Det er også derfor jeg er involveret $\mathrm{i}$ BLOXHUB. Jeg ser, at BLOXHUB engagerer hundredvis af udviklingsmiljøer, samtidig med at de forbinder alle de aktører, måske på den anden side af jorden, der er nødvendige for at man kan omdanne en idé til et konkret produkt og løsninger på samme tid.

Urbanisering er både et problem og en løsning, men der er helt sikkert et potentiale for en god forretning. Den danske tilgang til at designe bygninger og udvikle byer, baseret på en tilgang hvor mennesket er i centrum og på høje bæredygtighedsstandarder, er meget attraktiv både for folk i Danmark og i udlandet. Det er det potentiale, som vi forsøger at indfri i BLOXHUB.

Kan man observere, at byer også har en tiltagende rolle i udviklingslandene?

Udviklingslande er ikke ensartede, så man kan ikke sige noget generelt om det. Men der er byer i udviklingslande, hvor de arbejder henimod at skabe deres egne lokale økosystemer i forhold til at skabe bæredygtig vækst, og hvor inklusion er en absolut nødvendighed. Fx når man designer infrastrukturen således, at fattige mennesker let og billigt kan komme på arbejde, enten på cykler eller ved hjælp af effektiv offentlig transport, som det sker i Columbias storbyer.

Grundlæggende kan man konstatere, at flere steder i Latinamerika sker der store spring i udviklingen netop gennem urbaniseringen. I forhold til byer i samfund af mere autoritær karakter som Rusland er problemet hovedsageligt, at deres produktion og økonomi baserer sig på industriproduktion og udvinding af råstoffer.
For dem vil det være afgørende at åbne deres økonomi for teknisk innovation og samarbejde. Dertil kommer, at rammebetingelserne skal være på plads i form af de juridiske og retslige rammer baseret på retssikkerhed og retssamfund, for at det skal lykkes at gøre byerne til succesrige metropoler.

I 2015 vedtog man i FN de globale udviklingsmål, hvor boredygtig urbanisering har sit eget mål. Har det en voerdi?

Når alt kommer til alt er det godt at have globale udviklingsmål. Men jeg tror, at vi befinder os i en verden, som kræver konkrete svar på konkrete problemer, såsom flygtninge, inklusion, integration, klima, sundhed og velfærd.

Byerne er organismer, de tilpasser sig og finder svar og løsninger på konkrete problemer. Ideologi og politik kommer ikke i vejen, fordi de ansvarlige myndigheder og politikere er direkte ansvarlige over for borgerne. Det er en helt anden måde at skabe løsninger på.

Med andre ord står vi over for en verden, som er drevet af byer, i og med at de har en indbygget evne til på meget større skala at tage initiativet og rykke først, samtidig med, at deres løsninger hurtig spredes til andre byer, der så tilpasser disse løsninger til deres egne særlige behov og omstændigheder.

Hvad kommer byernes revolution til at betyde for vores demokratier?

Byer og metropoler udgør aktive og medinddragende demokratier. I en by er der hundrede, hvis ikke tusinde ledere, som kollektivt tager ansvar og leder hver deres område i samarbejde med andre enheder.

Politik på landsplan repræsenterer på mange måder det passive repræsentati- 
ve demokrati. Borgernes eneste rolle er at stemme på forudbestemte tidspunkter. Det er vigtigt for mig at understrege, at det vi er vidne til, når det gælder byernes stærke fremkomst, er en fundamental samfundsmæssig forandring. Forandringer, der skabes nedefra, og som vil føre til forandringer i forholdet mellem individ og stat. Når den politiske handlekraft er decentraliseret og delegeret ned til byerne og byernes øverste myndigheder, så vil der også ske et skifte i borgernes rolle i relation til staten.

I byerne er der et væld af aktører, som har indflydelse, myndighed og mulighed for at agere. Omvendt virker det på landsplan ofte, som om der kun er en håndfuld aktører, og de er derfor svæ- re at få adgang til, da der vil være rift om deres tid. Så den strukturelle forandring, som vi oplever, når byerne bliver stærke aktører, er en meget hurtig form for decentralisering af magt, som giver helt nye og mange flere aktører mulighed for indflydelse og frisættelse i forhold til indflydelse på deres egen dagligdag.

Byernes revolution vil have som konsekvens, at forholdet mellem borger og stat demokratiseres, og derved åbnes der op for et langt mere deltagende og medinddragende demokrati. Det skaber formentlig et mere modstandsdygtigt samfund med myndige borgere. Og derved mere plads til innovation. 